\title{
L-a-phosphatidylglycerol chlorohydrins as potential biomarkers for chlorine gas exposure
}

\author{
Petrus Hemström, Andreas Larsson, Linda Elfsmark and Crister Åstot* \\ The Swedish Defense Research Agency, FOI CBRN Defense and Security, 90182 Umeå.
}

\begin{abstract}
Animal models, synthesis of reference chemicals, analytical methods and quantitative analysis
\end{abstract}

\section{Animal models of lung disease}

Animals

For studies of airway inflammation C57BL/6J mice, originally obtained from Jackson Laboratories (Bar Harbor, ME), were bred in our animal facility. All mice were between 9 and 10 weeks old when experiments were initiated. Animals were fed standard chow and water $a d$ libitum. The study was approved by the Regional Animal Research Ethics Committee according to national laws.

\section{Allergen-induced airway inflammation}

Mice were sensitized (n=6) with $200 \mu \mathrm{L}(50 \mu \mathrm{g} / \mathrm{mL})$ ovalbumin (OVA, Chicken egg albumin grade V, Sigma, St. Louis, MO) adsorbed to aluminium hydroxide gel (1:3) by intraperitoneal (i.p.) injection at day 0 and 14. On days 29, 32 and 34 mice were subjected to an aerosol of OVA for 30 min using a nose-only Battelle exposure chamber. Aerosol was generated using a nebulizer concentration of $10 \mathrm{mg}$ protein $/ \mathrm{mL}$ dissolved in phosphate-buffered saline (PBS) with $\mathrm{pH} 7.4$ according to a protocol previously described ${ }^{1}$. Control mice $(n=4)$ were given no other treatment than aerosolized OVA at day 29, 32 and 34.

At day 35 the animals were sacrificed, tracheostomized and their lungs were lavaged with ice cold HBSS (4 x 1 ml). The bronchoalveolar lavage fluid (BALF) were aliquoted and frozen at $-80{ }^{\circ} \mathrm{C}$ until analysis. The cells in the BALF were counted and stained with May-Grünwald Giemsa before being differentiated using light microscopy. Mice that were pre-sensitized with OVA displayed a prominent airway inflammation at day 35. When compared to controls, sensitized mice had significantly increased numbers of leukocytes $(3150000 \pm 593000$ respectively 47900 \pm 10200 ), eosinophils (2630000 \pm 501000 respectively $0.000 \pm 0.000$ ), neutrophils $(76900 \pm 14500$ respectively 538 \pm 312$)$ and lymphocytes $(327000 \pm 65700$ respectively $3510 \pm 1590)$.

Melphalan-induced lung injury

Melphalan (4-[bis(2-chloroethyl)amino]-1-phenylalanine) (Sigma-Aldrich, St Louis, MO), a nitrogen mustard analogue, was dissolved in phosphate-buffered-saline (PBS, Sigma-Aldrich, St Louis, MO) according to a previously described method ${ }^{2}$ to a final concentration of 0.67 $\mathrm{mg} / \mathrm{ml}$. Melphalan $(50 \mu \mathrm{l})$ was administered by tracheal instillation to anesthetized mice at a dose of $1 \mathrm{mg} / \mathrm{kg}$ body weight $(\mathrm{n}=6-7)$. Control mice received vehicle alone $(\mathrm{n}=5-7)$. The toxic effects after inhalation of melphalan was evaluated in BALF at $24 \mathrm{~h}$ after exposure. Exposure 
to melphalan induced a pulmonary inflammation in mice with significantly increased numbers of leukocytes (1260000 \pm 146000$)$ and neutrophils (1120000 149000$)$ in BALF when compared to controls ( $114000 \pm 20200$ respectively $22600 \pm 15600)$.

\section{Statistics}

The results of chlorine and allergen induced airway inflammation in mice are expressed as mean values \pm standard error of the mean. Differences between the means of controls and chlorine exposed groups was determined by one-way analysis of variance (ANOVA) followed by Dunnett's post-test using GraphPad Prism Version 6.0 (GraphPad Software, La Jolla, CA). A statistical result of $\mathrm{p}<0.05$ was considered significant $(* \mathrm{p}<0.05, * * \mathrm{p}<0.01$ and $* * * * \mathrm{p}<0.001)$. 


\section{Synthesis of lipid reference materials}

\section{General}

All reactions were carried out under an inert atmosphere with dry solvents, unless otherwise stated. TLC was performed on Silica Gel $60 \mathrm{~F}_{254}$ using detection with UV light and staining with potassium permanganate or cerium molybdate. The ${ }^{1} \mathrm{H},{ }^{31} \mathrm{P}$ and ${ }^{13} \mathrm{C}$ NMR spectra were recorded at $298 \mathrm{~K}$ with a Bruker DRX-500 and calibrated using the residual peak of solvent as internal standard $\left[\mathrm{CDCl}_{3}\left(\mathrm{CHCl}_{3} \delta \mathrm{H} 7.26 \mathrm{ppm}, \mathrm{CDCl}_{3} \delta \mathrm{C} 77.16 \mathrm{ppm}\right)\right]$. Preparative HPLC purification was carried out on a Waters system equipped with a Aquity Qda massdetector and a Hichrom kromasil $5 \mu \mathrm{m} 21.2$ x $250 \mathrm{~mm}$ column with an isocratic Hexane/iPrOH/H2O (65:30:5) eluent system, a flow rate of $20 \mathrm{~mL} / \mathrm{min}$ and mass detection at negative ionization set to 799.5 .
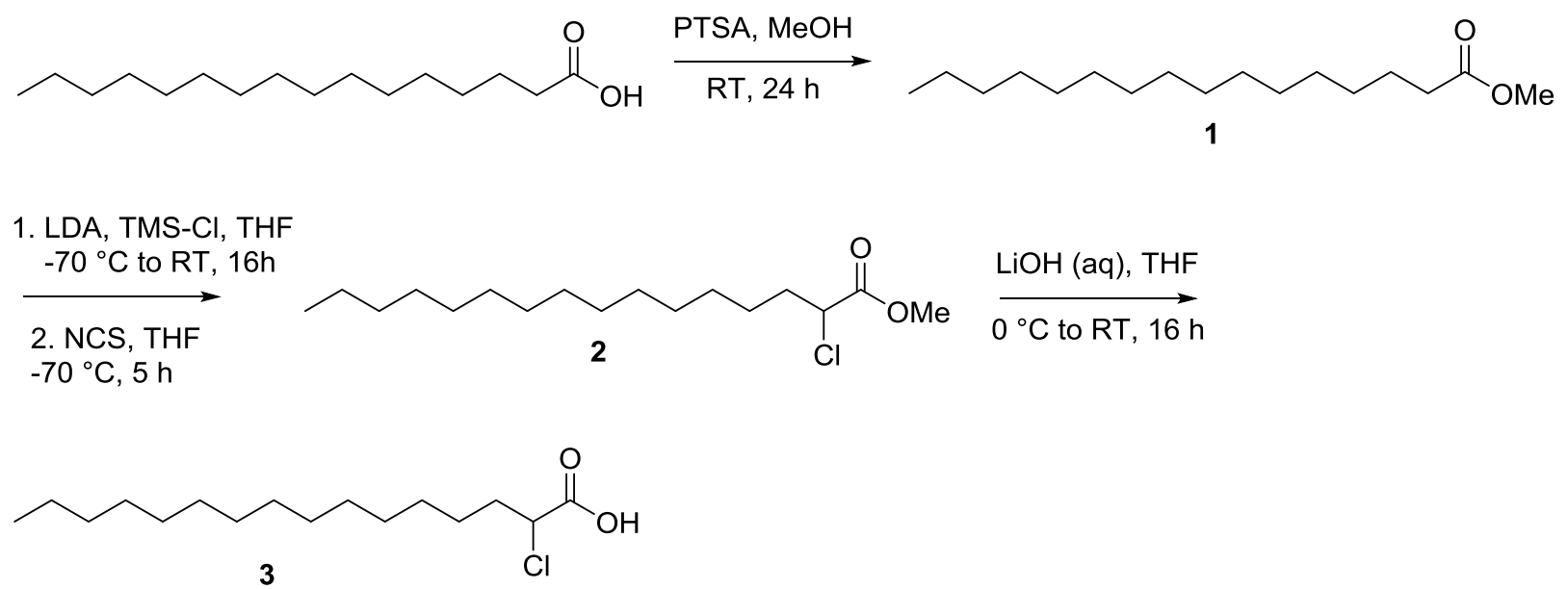

Scheme 1. Synthesis of 2-chlorohexadecanoic acid (3)

\section{Methyl palmitate (1)}

Palmitic acid (1.50 g, $5.85 \mathrm{mmol})$ and 4-methylbenzenesulfonic acid (PTSA) (cat.) was added in $\mathrm{MeOH}(30 \mathrm{~mL})$ and stirred for $24 \mathrm{~h}$ before concentrated. The reaction mixture was diluted with ethyl acetate and washed $2 \times 20 \mathrm{~mL}$ with $1 \mathrm{M}$ sodium hydroxide and 1 x $20 \mathrm{~mL}$ with brine. The organic phase was dried (sodium sulfate) and concentrated to give 1 (1.54 g, $5.69 \mathrm{mmol}$, $97 \%$ yield).

${ }^{1} \mathrm{H}$ NMR $\left(500 \mathrm{MHz}, \mathrm{CDCl}_{3}\right) \delta 3.68(\mathrm{~s}, 3 \mathrm{H}), 2.32(\mathrm{t}, J=7.5 \mathrm{~Hz}, 2 \mathrm{H}), 1.68-1.25(\mathrm{~m}, 26 \mathrm{H}), 0.90$ (t, $J=6.8 \mathrm{~Hz}, 3 \mathrm{H})$.

Methyl 2-chloropalmitate (2)

To a cooled solution $\left(-70{ }^{\circ} \mathrm{C}\right)$ of lithium diisopropylamide (LDA) $(2.77 \mathrm{mmol})$, prepared at 0 ${ }^{\circ} \mathrm{C}$ by adding butyllithium $\left.(1.11 \mathrm{~mL}, 2.77 \mathrm{mmol})\right)$ to diisopropylamine $(0.400 \mathrm{ml}, 2.77 \mathrm{mmol})$ in $6 \mathrm{~mL}$ of dry tetrahydrofuran (THF), was added successively chlorotrimethylsilane (TMS-Cl) 
$(0.35 \mathrm{ml}, 2.77 \mathrm{mmol})$, and dropwise, methyl palmitate $(0.5 \mathrm{~g}, 1.85 \mathrm{mmol})$ in $2 \mathrm{~mL}$ of THF. The resulting solution was stirred while warming up to RT overnight. The solvents were evaporated in vacuo, and the residue was taken up in pentane, filtrated and concentrated to afford the crude silylenolether of methyl palmitate.

N-Chlorosuccinimide (NCS) $(0.37 \mathrm{~g}, 2.77 \mathrm{mmol})$ was added to a cooled solution $\left(-70^{\circ} \mathrm{C}\right)$ of the crude silylenolether in $15 \mathrm{~mL}$ of THF. After $5 \mathrm{~h}, 15 \mathrm{~mL}$ of aqueous sodium thiosulfate $(0.4 \mathrm{M})$ was added and the mixture was extracted with diethyl ether. The organic layer was washed with sodium thiosulfate $(0.4 \mathrm{M})$ and water, dried over sodium sulfate, and concentrated to afford 2 (0.56 mg, $1.84 \mathrm{mmol}, 99 \%$ yield)

${ }^{1} \mathrm{H}$ NMR $\left(500 \mathrm{MHz}, \mathrm{CDCl}_{3}\right) \delta 4.28(\mathrm{dd}, J=8.1,6.0 \mathrm{~Hz}, 1 \mathrm{H}), 3.79(\mathrm{~s}, 3 \mathrm{H}), 2.06-1.87(\mathrm{~m}, 2 \mathrm{H})$, 1.53-1.17 (m, 24H), $0.90(\mathrm{t}, J=6.8 \mathrm{~Hz}, 3 \mathrm{H})$.

\section{2-chlorohexadecanoic acid (3)}

Methyl 2-chloropalmitate (280 $\mathrm{mg}, 0.92 \mathrm{mmol})$ was dissolved in THF (6 mL), then a solution of lithium hydroxide $(33 \mathrm{mg}, 1.38 \mathrm{mmol})$ in water $(3 \mathrm{~mL})$ was added at $0{ }^{\circ} \mathrm{C}$. The mixture was stirred overnight, acidified with $1 \mathrm{M}$ hydrochloric acid, and then extracted 3 x $10 \mathrm{~mL}$ with dichloromethane. The combined organic phases was dried and evaporated to afford $\mathbf{3}$ (258 $\mathrm{mg}, 0.89 \mathrm{mmol}, 97 \%$ yield)

${ }^{1} \mathrm{H} \mathrm{NMR}\left(500 \mathrm{MHz}, \mathrm{CDCl}_{3}\right) \delta 4.35(\mathrm{dd}, J=8.1,5.8 \mathrm{~Hz}, 1 \mathrm{H}), 2.11-1.92(\mathrm{~m}, 2 \mathrm{H}), 1.67-1.20(\mathrm{~m}$, $24 \mathrm{H}), 0.88(\mathrm{t}, J=6.8 \mathrm{~Hz}, 3 \mathrm{H})$.
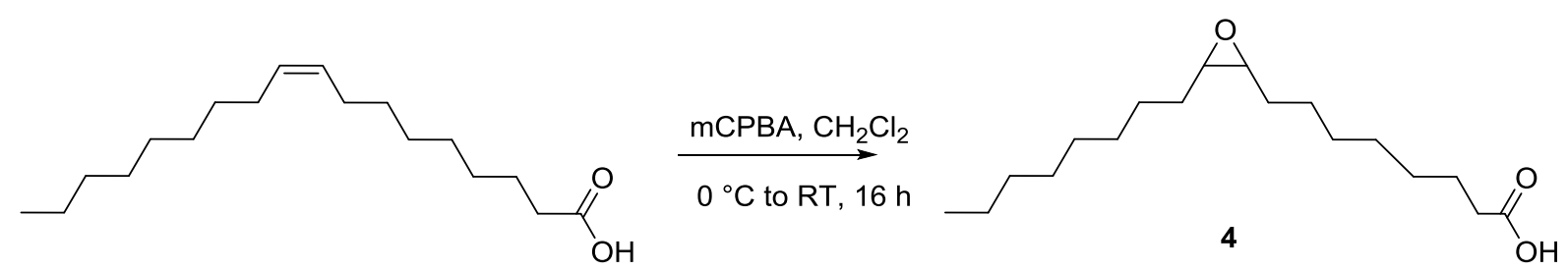

Scheme 2. Synthesis of 9,10-Epoxyoctadecanoic acid (4)

\section{9,10-Epoxyoctadecanoic acid (4)}

$40 \%$ 3-Chloroperoxybenzoic acid (mCPBA) (4487 $\mathrm{mg}, 10.40 \mathrm{mmol}$ ) was added in one portion to a solution of oleic acid $(2260 \mathrm{mg}, 8 \mathrm{mmol})$ in $\mathrm{CH}_{2} \mathrm{Cl}_{2}(20 \mathrm{~mL})$ cooled in an ice/water bath under air. The resulting white suspension was allowed to warm up to room temperature while stirring overnight. The reaction was quenched with sat. aq. sodium thiosulfate solution $(20 \mathrm{~mL})$ and extracted with diethyl ether $(3 \times 20 \mathrm{~mL})$, dried over sodium sulfate and concentrated to give 4 (1833 mg, $6.14 \mathrm{mmol}, 77 \%$ yield)

${ }^{1} \mathrm{H}$ NMR (500 MHz, $\left.\mathrm{CDCl}_{3}\right) \delta$ 2.97-2.91 (m, 2H), $2.38(\mathrm{t}, J=7.5,2 \mathrm{H}), 1.70-1.25(\mathrm{~m}, 26 \mathrm{H})$, $0.90(\mathrm{t}, J=7.1 \mathrm{~Hz}, 3 \mathrm{H})$. 

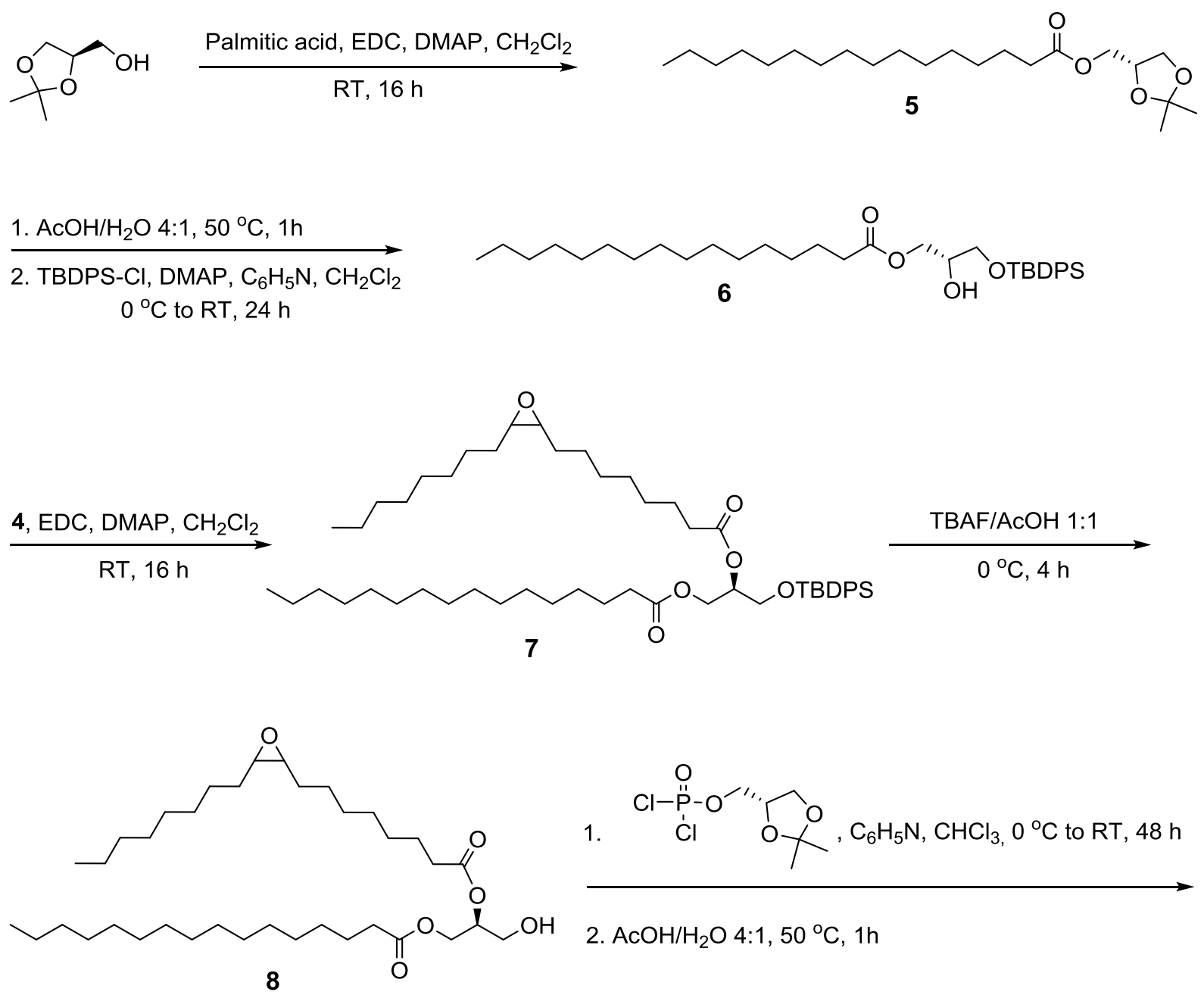

2. $\mathrm{AcOH} / \mathrm{H}_{2} \mathrm{O} 4: 1,50^{\circ} \mathrm{C}, 1 \mathrm{~h}$<smiles>CCCCCCCCCCCCCCCCC(=O)OC[C@H](COP(=O)(O)OC[C@H](O)CO)OC(=O)CCCCCCCCC(Cl)C(O)CCCCCCCC</smiles><smiles>CCCCCCCCCCCCCCCCCC(O)C(Cl)CCCCCCCCCC(=O)OC[C@H](COP(=O)(O)OC[C@H](O)CO)OC(=O)CCCCCCCC</smiles>

Scheme 3. Synthesis of hydrochlorinated PG (9a, 9b)

(S)-(2,2-dimethyl-1,3-dioxolan-4-yl)methyl palmitate (5)

A mixture of (R)-(-)-2,2-Dimethyl-1,3-dioxolane-4-methanol (0.995 ml, $8 \mathrm{mmol})$, palmitic acid $(2.051 \mathrm{~g}, 8.00 \mathrm{mmol})$, EDC.HCl (1.687 g, $8.80 \mathrm{mmol})$, and DMAP (0.098 g, 0.800 
mmol) in dry $\mathrm{CH}_{2} \mathrm{Cl}_{2}(60 \mathrm{ml})$ was stirred at ambient temperature for $16 \mathrm{~h}$. The mixture was concentrated on a rotary evaporator diluted with water $(15 \mathrm{~mL})$, and extracted with $\mathrm{Et}_{2} \mathrm{O}(3 \mathrm{x}$ $15 \mathrm{~mL}$ ). The combined organic extracts were washed with brine, dried with anhydrous $\mathrm{Na}_{2} \mathrm{SO}_{4}$ and concentrated. Flash chromatography (16:1, Heptane/EtOAc) on silicagel gave 5 (2.2 $\mathrm{g}, 5.94 \mathrm{mmol}, 74 \%$ yield) as a white solid.

${ }^{1} \mathrm{H}$ NMR $\left(500 \mathrm{MHz}, \mathrm{CDCl}_{3}\right) \delta$ 4.34-4.28 (m, 1H), $4.16(\mathrm{dd}, J=11.5,4.8 \mathrm{~Hz}, 1 \mathrm{H}), 4.08(\mathrm{dd}, J$ $=11.5,4.8 \mathrm{~Hz}, 1 \mathrm{H}), 4.07(\mathrm{dd}, J=8.5,6.2 \mathrm{~Hz}, 1 \mathrm{H}), 3.73(\mathrm{dd}, J=8.5,6.2 \mathrm{~Hz}, 1 \mathrm{H}), 2.33(\mathrm{t}, J=$ $7.7 \mathrm{~Hz}, 2 \mathrm{H}), 1.66-1.57(\mathrm{~m}, 2 \mathrm{H}), 1.43(\mathrm{~s}, 3 \mathrm{H}), 1.37$ (s, 3H), 1.32-1.21 (m, 24H), 0.87 (t, J = 6.7 $\mathrm{Hz}, 3 \mathrm{H}) .{ }^{13} \mathrm{C}$ NMR $\left(125 \mathrm{MHz}, \mathrm{CDCl}_{3}\right) \delta 173.7,109.8,73.7,66.3,64.5,34.1,31.9,29.7(2 \mathrm{C})$, 29.7, 29.7 (2C), 29.6, 29.5, 29.4, 29.3, 29.1, 26.7, 25.4, 24.9, 22.7, 14.1 .

(R)-3-((tert-butyldiphenylsilyl)oxy)-2-hydroxypropyl palmitate (6)

A solution of $5(2 \mathrm{~g}, 5.40 \mathrm{mmol})$ in $\mathrm{AcOH}(48 \mathrm{ml})$ and water $(12 \mathrm{ml})$ was stirred at $50{ }^{\circ} \mathrm{C}$ for $60 \mathrm{~min}$. The heating bath was removed, and $\mathrm{NaHCO} 3$ (saturated aq.; $60 \mathrm{~mL}$ ) was added. The mixture was extracted with EtOAc $(3 \times 60 \mathrm{~mL})$. The combined organic extracts were washed with brine, dried with anhydrous $\mathrm{Na}_{2} \mathrm{SO}_{4}$ and concentrated to afford the crude diol in a quantitative yield which was used without further purification.

The crude diol $(1.00 \mathrm{~g}, 3.00 \mathrm{mmol})$ was dissolved in $\mathrm{CH}_{2} \mathrm{Cl}_{2}(7.5 \mathrm{~mL})$, pyridine $(0.73 \mathrm{~mL}$, $9.00 \mathrm{mmol})$ and DMAP (37 mg, $0.30 \mathrm{mmol})$, to which was added TBDPS-Cl $(0.85 \mathrm{~mL}, 3,30$ mmol) at $0{ }^{\circ} \mathrm{C}$. After the mixture was stirred for $24 \mathrm{~h}$ at RT, it was quenched with $5 \mathrm{ml}$ of $1 \mathrm{~N}$ $\mathrm{HCI}$, and extracted with $\mathrm{CH}_{2} \mathrm{Cl}_{2}$. The combined organic fractions was dried with anhydrous $\mathrm{Na}_{2} \mathrm{SO}_{4}$ and concentrated. Flash chromatography (4:1, Heptane/EtOAc) on silicagel gave 6 (1.52 g, $2.67 \mathrm{mmol}, 89 \%$ yield) as a colourless oil.

${ }^{1} \mathrm{H}$ NMR $\left(500 \mathrm{MHz}, \mathrm{CDCl}_{3}\right) \delta$ 7.67-7.63 (m, 4H), 7.42-7.36 (m, 6H), 4.21-4.13 (m, 2H), 3.93 (sex., $J=5.2 \mathrm{~Hz}, 1 \mathrm{H}), 3.73-3.64(\mathrm{~m}, 2 \mathrm{H}), 2.53(\mathrm{~d}, J=5.2 \mathrm{~Hz}, 1 \mathrm{H}), 2.29(\mathrm{t}, J=7.5 \mathrm{~Hz}, 2 \mathrm{H})$, 1.63-1.54 (m, 2H), 1.32-1.21 (m, 24H), $1.07(\mathrm{~s}, 9 \mathrm{H}), 0.88(\mathrm{t}, J=6.8 \mathrm{~Hz}, 3 \mathrm{H}) .{ }^{13} \mathrm{C} \mathrm{NMR}(125$ $\left.\mathrm{MHz}, \mathrm{CDCl}_{3}\right) \delta 174.0,135.5$ (4C), 132.9 (2C), 129.9 (2C), 127.8 (4C), 70.1, 65.0, 64.4, 34.2, 31.9, 29.7 (2C), 29.7, 29.7 (2C), 29.6, 29.5, 29.4, 29.3, 29.2, 26.8 (3C), 24.9, 22.7, 19.2, 14.1.

(2R)-3-((tert-butyldiphenylsilyl)oxy)-2-((9,10-epoxy)oleoyl)propyl palmitate (7)

A mixture of $6(1.35 \mathrm{~g}, 2.37 \mathrm{mmol}), 4(0.84 \mathrm{~g}, 2.61 \mathrm{mmol}), \mathrm{EDC} . \mathrm{HCl}(0.55 \mathrm{~g}, 2.85 \mathrm{mmol})$ and DMAP (29 mg, $0.24 \mathrm{mmol})$ in dry $\mathrm{CH}_{2} \mathrm{Cl}_{2}(24 \mathrm{ml})$ was stirred at ambient temperature for 16 $\mathrm{h}$. The mixture was concentrated on a rotary evaporator and water $(30 \mathrm{~mL})$ was added. The mixture was extracted with $\mathrm{Et}_{2} \mathrm{O}(3 \times 50 \mathrm{~mL})$. The combined organic extracts were washed with brine, dried with anhydrous $\mathrm{Na}_{2} \mathrm{SO}_{4}$ and concentrated. Flash chromatography (16:1, Heptane/EtOAc) on silicagel gave 7 (2.00 g, $2.36 \mathrm{mmol}, 99 \%$ yield).

${ }^{1} \mathrm{H}$ NMR $\left(500 \mathrm{MHz}, \mathrm{CDCl}_{3}\right) \delta$ 7.67-7.63 (m, 4H), 7.42-7.36 (m, 6H), 5.20-5.14 (m, 1H), 4.40 $(\mathrm{dd}, J=11.8,3.9 \mathrm{~Hz}, 1 \mathrm{H}), 4.21(\mathrm{dd}, J=11.8,6.2 \mathrm{~Hz}, 1 \mathrm{H}), 3.80-3.72(\mathrm{~m}, 2 \mathrm{H}), 2.92-2.86(\mathrm{~m}$, 2H), 2.33-2.21 (m, 4H), 1.64-1.20 (m, 52H), $1.04(\mathrm{~s}, 9 \mathrm{H}), 0.88(\mathrm{t}, J=6.8 \mathrm{~Hz}, 6 \mathrm{H}) .{ }^{13} \mathrm{C} \mathrm{NMR}$ 
(125 MHz, $\mathrm{CDCl}_{3}$ ) $\delta 173.4,173.0,135.5$ (4C), 133.0 (2C), 129.8 (2C), 127.8 (4C), 71.5, 62.3

(2C), 57.2 (2C), 34.3, 34.1, 31.9 (2C), 29.7 (2C), 29.7, 29.7 (2C), 29.6, 29.5 (3C), 29.4 (2C), 29.3, 29.2 (2C), 29.1, 29.0, 27.8 (2C), 26.7 (3C), 26.6, 26.5, 24.9 (2C), 22.7 (2C), 19.2, 14.1 (2C).

(2S)-3-hydroxy-2-(((9,10-epoxy)oleoyl)propyl palmitate (8)

A solution of 7 (650 mg, $0.77 \mathrm{mmol})$ in THF ( $8 \mathrm{~mL})$ was treated with a solution of TBAF (1 $\mathrm{M}$ in THF, 0,842 $\mathrm{mL}, 0,842 \mathrm{mmol})$ and acetic acid $(0,048 \mathrm{~mL}, 0,842 \mathrm{mmol})$ in a 1:1 mixture at $0{ }^{\circ} \mathrm{C}$ under argon. The reaction mixture was stirred at $0{ }^{\circ} \mathrm{C}$ for $4 \mathrm{~h}$, then quenched with $\mathrm{NH}_{4} \mathrm{Cl}$ (aq, sat.) and extracted with $\mathrm{CH}_{2} \mathrm{Cl}_{2}$, dried with anhydrous $\mathrm{Na}_{2} \mathrm{SO}_{4}$ and concentrated. Flash chromatography (4:1, Heptane/EtOAc) on silicagel gave 8 (440 mg, 0.72 mmol, $94 \%$ yield) as a colourless oil.

${ }^{1} \mathrm{H}$ NMR $\left(500 \mathrm{MHz}, \mathrm{CDCl}_{3}\right) \delta 5.10-5.05(\mathrm{~m}, 1 \mathrm{H}), 4.31(\mathrm{dd}, J=11.9,4.6 \mathrm{~Hz}, 1 \mathrm{H}), 4.23(\mathrm{dd}, J$ $=12.0,5.7 \mathrm{~Hz}, 1 \mathrm{H}), 3.94-3.85(\mathrm{~m}, 2 \mathrm{H}), 2.87-2.72(\mathrm{~m}, 2 \mathrm{H}), 2.34(\mathrm{t}, J=7.4 \mathrm{~Hz}, 2 \mathrm{H}), 2.31(\mathrm{t}, J$ $=7.7 \mathrm{~Hz}, 2 \mathrm{H}), 1.66-1.21(\mathrm{~m}, 52 \mathrm{H}), 0.87(\mathrm{t}, J=7.2 \mathrm{~Hz}, 6 \mathrm{H}) .{ }^{13} \mathrm{C} \mathrm{NMR}\left(125 \mathrm{MHz}, \mathrm{CDCl}_{3}\right)$ $\delta 173.8,173.3,72.1,61.9,61.5,57.2(2 \mathrm{C}), 34.2,34.1,31.9,31.8,29.7$ (2C), 29.7, $29.6(3 \mathrm{C})$, 29.5 (2C), 29.4, 29.3 (2C), 29.2 (2C), 29.1 (2C), 29.0, 28.9, 27.8 (2C), 26.6 (2C), 24.9, 24.8, 22.7, 22.6, $14.1(2 \mathrm{C})$.

(R,S)-1-Palmitoyl-2-(9-chloro-10-hydroxyoctadecanoic acid)-phosphatidylglycerol (9a) and (R,S)-1-Palmitoyl-2-(10-chloro-9-hydroxyoctadecanoic acid)-phosphatidylglycerol (9b)

A chloroform solution $(0.3 \mathrm{ml})$ containing quinoline $(44 \mathrm{mg}, 0.34 \mathrm{mmol})$ was added dropwise to a cooled chloroform solution $(0.3 \mathrm{ml})$ containing $(\mathrm{R})-(-)-2,2-D i m e t h y l-1,3-$ dioxolane-4methanol (27 mg, $0.20 \mathrm{mmol})$ and freshly distilled phosphorus oxychloride (31 mg, 0.20 mmol). The mixture was stirred for $60 \mathrm{~min}$ at $\mathrm{RT}$ and $30 \mathrm{~min}$ at $35^{\circ} \mathrm{C}$, then cooled down in an ice bath. To this mixture a solution of $8(100 \mathrm{mg}, 0.16 \mathrm{mmol})$ in chloroform $(1.5 \mathrm{~mL})$ was added, warmed to RT and stirred for $48 \mathrm{~h}$ before water $(5 \mathrm{uL})$ was added. The resulting mixture was stirred for an additional hour at RT before concentrated. The residue was suspended in water and extracted with $\mathrm{Et}_{2} \mathrm{O}$, with anhydrous $\mathrm{Na}_{2} \mathrm{SO}_{4}$ and concentrated. The crude acetal protected phosphatidyl glycerol was dissolved in $\mathrm{AcOH}(1 \mathrm{ml})$ and water $(0.25$ $\mathrm{ml})$ and stirred at $50{ }^{\circ} \mathrm{C}$ for $60 \mathrm{~min}$. The heating bath was removed, and $2 \mathrm{M} \mathrm{HCl}(1.5 \mathrm{~mL})$ was added. The mixture was extracted with EtOAc $(3 \times 5 \mathrm{~mL})$. The combined organic extracts were washed with brine, dried with anhydrous $\mathrm{Na}_{2} \mathrm{SO}_{4}$ and concentrated. Purification by prepararative HPLC afforded a mixture of $\mathbf{9 a}$ and $\mathbf{9 b}$ as a colourless oil.

${ }^{1} \mathrm{H}$ NMR $\left(500 \mathrm{MHz}, \mathrm{CDCl}_{3}\right) \delta$ 5.26-5.19 (m, 1H), 4.38-4.26 (m, 1H), 4.22-4.00 (m, 5H), 3.94$3.85(\mathrm{~m}, 1 \mathrm{H}), 3.76-3.57(\mathrm{~m}, 2 \mathrm{H}), 3.05(\mathrm{bs}, 2 \mathrm{H}), 2.33(\mathrm{t}, J=7.4 \mathrm{~Hz}, 2 \mathrm{H}), 2.30(\mathrm{t}, J=7.7 \mathrm{~Hz}$, $2 \mathrm{H}), 1.66-1.21(\mathrm{~m}, 52 \mathrm{H}), 0.87(\mathrm{t}, J=7.2 \mathrm{~Hz}, 6 \mathrm{H}) .{ }^{31} \mathrm{P} \mathrm{NMR}\left(202 \mathrm{MHz}, \mathrm{CDCl}_{3}\right) \delta-0.49$. ESIMS $m / z,\left[\mathrm{M}-\mathrm{H}^{+}\right]^{-}$calcd 799.5; found 799.6. 


\section{Analytical methods}

The initial sample preparation method dissolving the sample in $10 \%$ ethanol was not ideal since a rapid loss of our biomarker was noted. After identification and synthesis a study was made to improve sample stability. It was concluded that up to $50 \%$ ethanol in the sample solvent still gave quantitative trapping in the sample loading step (however more polar compounds are not trapped and can thus not be analyzed). Sample stability was greatly improved but is still an issue and samples stored in sample vials over night. Stored samples that was evaporated to dryness and reconstituted again gave the same response as the previous day. It is thus recommended that the samples are stored dry.

\section{Qualitative analysis}

Although we chose to focus on the phosphatidylglycerol chlorohydrins in our search for an unambiguous biomarker for chlorine also $\alpha$-chlorinated fatty acids could be detected in relatively high concentrations in BAL fluid from chlorine exposed mice. We also noted an absence of fatty acid chlorohydrins, the reaction product between hypochlorous acid (or chlorine) and an unsaturated fatty acid.

Two of the main chlorinated ions detected in BAL fluid from chlorine exposed mice were $\mathrm{C}_{16} \mathrm{H}_{30} \mathrm{ClO}_{2}$ and $\mathrm{C}_{18} \mathrm{H}_{34} \mathrm{ClO}_{2}$ identified by their exact mass. The only likely compounds are chloro-palmitic and chloro-stearic acids. However, 9-chloro-stearic acid spiked into BAL fluid showed a longer retention time than the biomarker but had exactly the same mass. The most likely source of the chloro-fatty acids seen in BAL fluid from exposed mice is from the reaction of $\mathrm{HOCl}$ with the vinyl ether group of a plasmalogen ${ }^{3}$. This reaction would produce a chlorofatty acid with the chlorine in $\alpha$-position to the carboxyl. Synthesizing $\alpha$-chloro palmitic acid showed that it did indeed have shorter retention time than if the chlorine was situated further from the carboxylic acid group.

Using positive ion ESI we detected two high abundance compounds with $\mathrm{m} / \mathrm{z}$ of 748.5 $\left(\mathrm{C}_{40} \mathrm{H}_{80} \mathrm{ClNO}_{9} \mathrm{P}\right)$ and $812.5\left(\mathrm{C}_{42} \mathrm{H}_{84} \mathrm{ClNO} 9 \mathrm{P}\right)$ we could not identify them but they showed the characteristic chlorine isotope cluster (figure $\mathrm{S} 1$ ). 

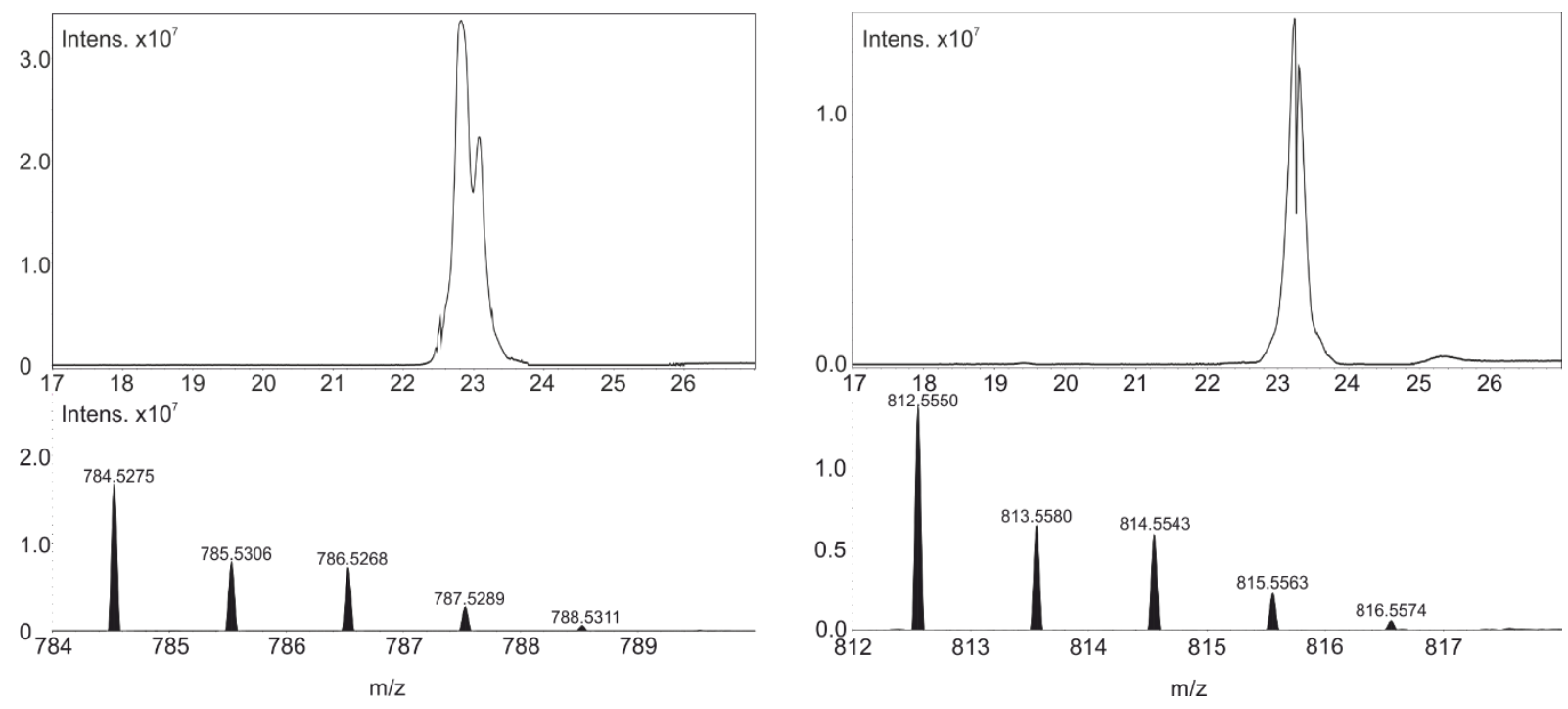

Figure S1: Chromatograms and HRMS spectra of 16:0-16:1 Phosphatidylcholine chlorohydrin (left) 16:0-18:1 Phosphatidylcholine chlorohydrin (right) from a chlorine exposed mouse.

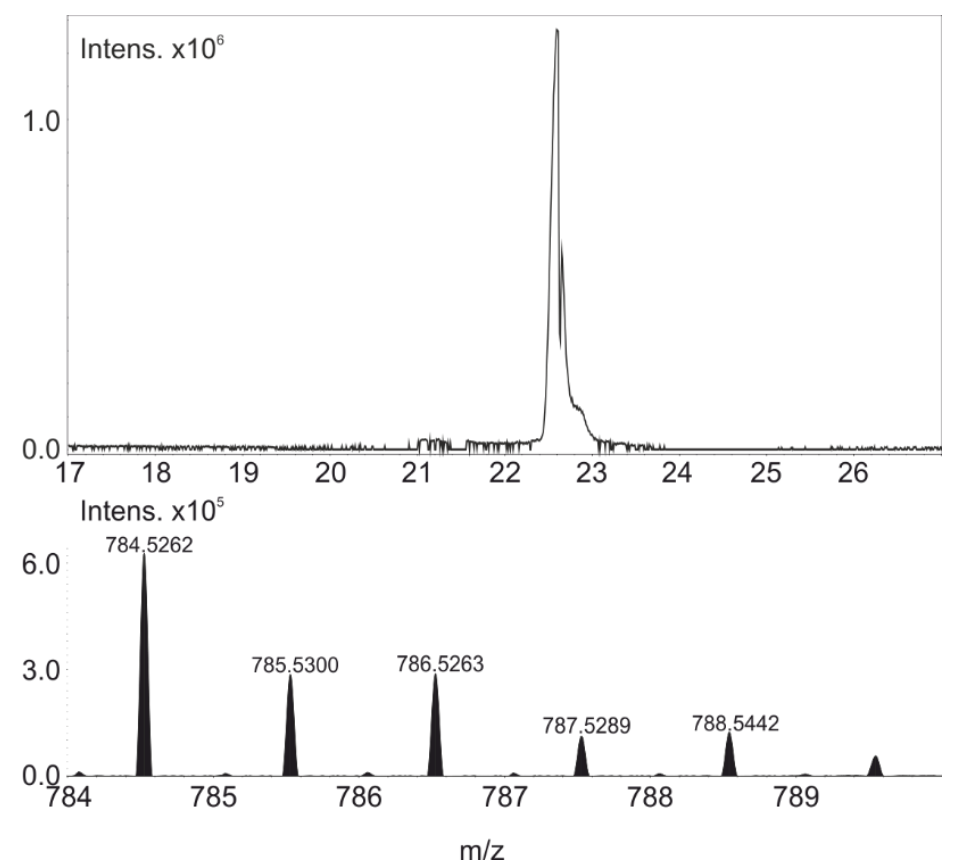

Figure S2: Chromatograms and HRMS spectra of 16:0-16:1 Phosphatidylcholine chlorohydrin standard from in-vitro chlorinated phosphatidylcholine.

When we succeeded in identifying the two unknowns found in negative mode ESI as phosphatidylglycerols it was reasonable to believe that the two found in positive mode could also be pulmonary surfactants i.e. phosphatidylcholines. Since these were found in high abundance we attempted to verify their identity. L- $\alpha$-Phosphatidylcholine was therefore chlorinated using the same method as had been used for L- $\alpha$-Phosphatidyl-DL-glycerol.

However the phosphatidylcholine chlorohydrins synthetized did not produce any unique fragments that could be used in an MS/MS method. The only fragment produced was 184 which corresponds to the phosphocholine moiety. We therefore did not pursue these compounds any more but since they are the more abundant biomarker produced in chlorine gas exposed mice they still merit mentioning. 
It should also be pointed out that the identification as phosphatidylcholine chlorohydrins is only tentative.

\section{Quantitative analysis}

Quantification of the phosphatidylglycerol chlorohydrin biomarker was challenging since no isotopically labelled internal standard was available. Using the synthesized chlorohydrin of palmitoyl-oleyl phosphatidylglycerol $(9 \mathrm{a}, 9 \mathrm{~b})$, the standard addition method was thus the only feasible route to quantification of the level in BALF from exposed mice.

Five $200 \mu \mathrm{L}$ samples of BALF from mice exposed to $200 \mathrm{ppm}$ chlorine was extracted. The extracts were pooled and split in five aliquots again and to each subsample the synthetized standard was added ( 0.5 to $25 \mathrm{ng}$ ). The final volume was made up to $100 \mu \mathrm{L}$ and analysed by LC-HRMS. The extracted ion chromatograms were integrated and the area response plotted vs the amount of standard added (Figure S3). The calculated intercept of the calibration curve was $8.7 \mathrm{ng}$ corresponding to a concentration of $54 \mathrm{nM}(43.5 \mathrm{ng} / \mathrm{mL})$ in the BALF samples.

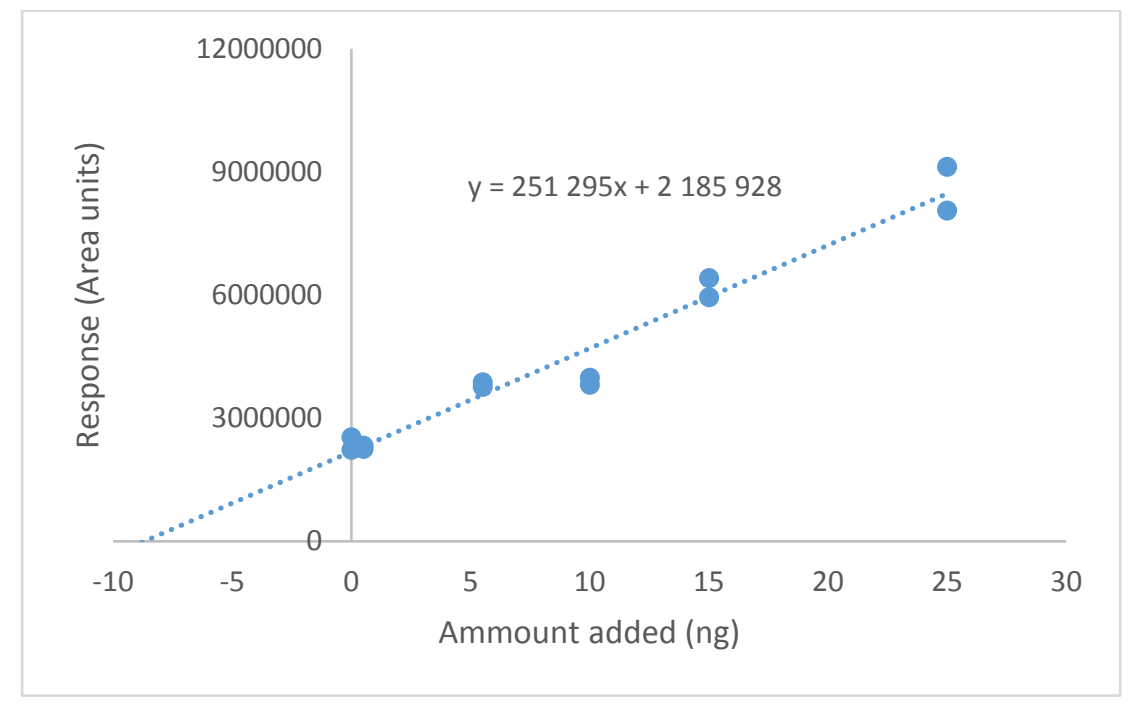

Figure S3. Standard addition of phosphatidylglycerol chlorohydrin standard to extracted BALF samples from mice exposed to 200ppm of chlorine gas for 15 minutes.

\section{References}

(1) Svensson, L.; Lilliehook, B.; Larsson, R.; Bucht, A. Immunology 2003, 108, 98-108.

(2) Wigenstam, E.; Jonasson, S.; Koch, B.; Bucht, A. Toxicology 2012, 301, 66-71.

(3) Skaff, O.; Pattison, D. I.; Davies, M. J. Biochemistry 2008, 47, 8237-8245. 